\title{
Parasites of pigs in two farms with poor husbandry practices in Bishoftu, Ethiopia
}

\author{
Authors: \\ Alemnesh Jufare ${ }^{1}$ \\ Nesibu Awol $^{2}$ \\ Fanos Tadesse ${ }^{3}$ \\ Yisehak Tsegaye ${ }^{2}$ \\ Birhanu Hadush \\ Affiliations: \\ ${ }^{1}$ Alage Agricultural Technical \\ Vocational Education Training \\ College, Ethiopia \\ ${ }^{2}$ College of Veterinary \\ Medicine, Mekelle University, \\ Ethiopia \\ ${ }^{3}$ College of Agricultural and \\ Veterinary Medicine, Addis \\ Ababa University, Ethiopia \\ Correspondence to: \\ Nesibu Awol \\ Email: \\ nesibuawol@yahoo.com \\ Postal address: \\ PO Box 2084, Mekelle, \\ Ethiopia \\ Dates: \\ Received: 26 June 2014 \\ Accepted: 27 Jan. 2015 \\ Published: 30 Apr. 2015 \\ How to cite this article: \\ Jufare, A., Awol, N., Tadesse, \\ F., Tsegaye, Y. \& Hadush, \\ B., 2015, 'Parasites of \\ pigs in two farms with \\ poor husbandry practices \\ in Bishoftu, Ethiopia', \\ Onderstepoort Journal of \\ Veterinary Research 82(1), \\ Art. \#839, 5 pages. http:// \\ dx.doi.org/10.4102/ojvr. \\ v82i1.839

\section{Copyright:} \\ (C) 2015. The Authors. \\ Licensee: AOSIS \\ OpenJournals. This work is \\ licensed under the Creative \\ Commons Attribution \\ License.
}

\section{Read online:}

A cross-sectional study was conducted from November 2011 to April 2012 on a total of 384 pigs from two privately owned intensive farms in Bishoftu, Ethiopia. The objectives of the study were to identify and determine the prevalence of common parasites of pigs. For the determination of gastrointestinal (GIT) parasites, faecal samples were collected from the study animals and subjected to standard parasitological examination techniques. Physical examination was conducted for the presence of skin parasitic lesions and skin scrapings were collected to determine prevalence of ectoparasites. The overall prevalence of GIT parasites in the pigs was 25\% (96/384). Examination of faecal samples revealed the ova or oocysts of four different gastrointestinal parasites, namely Coccidia (12\%), Strongyles (5.2\%), Ascaris suum (4.9\%) and Trichuris suis (2.9\%). Mixed infection by at least two parasite species was observed in $3.65 \%(14 / 384)$ of the pigs. The only ectoparasite species identified was Sarcoptes scabiei var. suis, with a prevalence of $2.6 \%$. This study indicates that pig parasites are a major problem in the study area, hence implementation of strategic control measures and appropriate hygienic management systems are recommended to reduce the prevalence of parasites.

\section{Introduction}

Pig production is the fastest growing livestock sector worldwide and this trend is expected to continue over the coming years. It is believed to mitigate the deficiency of animal protein and considered a tool to fight poverty in the tropics (Food and Agriculture Organization of the United Nations [FAO] 2012). Over the past decade, rearing of domestic pigs has become an increasingly popular livestock strategy in East Africa (Food and Agriculture Organization Statistics Division [FAOSTAT] 2005; Phiri et al. 2003). The lack of grazing land for ruminants and the recognition by farmers of quicker and higher returns on their investment have contributed to an increased interest in pig production (Phiri et al. 2003; Serres 2001). Pigs have lower social prestige than cattle, but they are inexpensive to raise and are therefore a popular option for resource-poor farmers (Dewey et al. 2011). Moreover, the high fecundity and feed conversion efficiency, early maturity, short generation interval, relatively small space requirement and ability to produce maximally under varied management conditions are some of the advantages of pig production compared to other livestock rearing (Lekule \& Kyvsgaard 2003). The growth in pig production plays an important role in contributing to national gross domestic product and general economic growth by providing an additional animal protein source for human consumption, generating employment and reducing poverty (Oluwafemi 2008).

Pig production in Ethiopia is believed to be in its infant stage (Hailu et al. 2014). The pig population in the country is estimated to be 29000 heads, representing $0.1 \%$ of the African pig population (FAOSTAT 2005). So far there are no large intensive swine farms in Ethiopia. Small-scale pig production as an agricultural activity was only recently introduced in all parts of Ethiopia and is mainly concentrated around the Bishoftu area. In many rural parts of Ethiopia, pig production is characterised by extensive production systems in which animals are allowed to scavenge at backyard and municipal garbage dumping sites (Abdu \& Gashaw 2010). This extensive husbandry system coupled with poor environmental hygiene and non-selective feeding behaviour of pigs has been indicated as a major risk factor for infection of pigs with helminths and other gastrointestinal (GIT) parasites; therefore pigs may act as potential reservoir hosts of human GIT parasites (Zewdneh et al. 2013).

GIT parasitic diseases constitute an important constraint to the pig industry in most parts of the world (Bakut, Shinggu \& Nwosu 1997; Onah \& Chiejina 1995). In the tropical and sub-tropical areas, as a result of minimum management attention given to pigs, parasitic infections in pigs are estimated to be second to African swine fever in importance and are major constraints to efficient pig production of all age groups (Hale, Stewart \& Marti 1986; Permin et al. 1999; Sangeeta, Prasad \& Singh 2002). The importance of parasitic diseases in pigs is chiefly economical as subclinical 
infection delays the achievement of market weight because of poor feed conversion rates, growth rate and general health status (Hale \& Stewart 1987; Stewart \& Hale 1988). Parasitic diseases also predispose pigs to concurrent infections by depressing the immunity of infected animals, whilst some can result in condemnation of organs or carcasses, causing additional losses in the pig industry (Hale \& Stewart 1998).

Several studies have been conducted to determine the occurrence and economic importance of parasites in pigs and various parasite species have been identified worldwide. These studies have identified Ascaris spp., Trichuris spp., Oesophagostomum spp., Trichinella spp., Strongylus spp. (Caballero-Hernández et al. 2004; Kagira et al. 2008; Nganga, Karanja \& Mutune 2008), Eimeria spp., Isospora spp. and Cryptosporidium spp. (Nosal \& Eckert 2005) as the most common GIT parasites of pigs. The most common external parasite of pigs is Sarcoptes scabiei var. suis, although in some cases they may be infested by Demodex phylloides and Haematopinus suis (Damriyasa et al. 2004; Davis \& Moon 1990). Information on epidemiological data and economic significance of GIT parasites in pigs in Ethiopia is scant. Available information is limited to a survey covering smallholder farmers in and around Holeta (Abdu \& Gashaw 2010), Burayu district (Kumsa \& Kifle 2014) and Tigray (Zewdneh et al. 2013), where Ascaris suum, Oesophagostomum spp., S. scabiei var. suis and Eimeria spp. were reported to be prevalent. Information on prevalence, types of parasite and management practices helps to formulate pig husbandry and extension programmes. In addition, knowledge about parasite species can be used as baseline information to design effective parasite control measures (Kumsa \& Kifle 2014). Therefore, this study was conducted in Bishoftu, Ethiopia, with the objective of determining the prevalence of common parasites and risk factors for their occurrence in intensively managed small-scale private pig farms.

\section{Material and methods \\ Study area}

The study was conducted from November 2011 to April 2012 in Bishoftu. This town is located at $9^{\circ} \mathrm{N}$ and $40^{\circ} \mathrm{E}$ in East Showa zone, Ada'aLiban district, Oromia Region, 47 km south-east of Addis Ababa. The altitude is about $1850 \mathrm{~m}$ above sea level. Bishoftu experiences an average annual rainfall of $800 \mathrm{~mm}$, having a bimodal pattern, with the main rainy season extending from June to September (during which $84 \%$ of the rain is expected) and the short rainy season from March to May. The mean annual minimum and maximum temperatures are $12{ }^{\circ} \mathrm{C}$ and $27^{\circ} \mathrm{C}$ respectively, with an overall average of $18.7^{\circ} \mathrm{C}$. The mean relative humidity is $61.3 \%$. It has three agro-ecological zones, namely midland (94\%), highland (3\%) and lowland (3\%) (National Metrological Surveillance Agency [NMSA] 2003).

\section{Study design and study animals}

A cross-sectional study was designed to address the objective of this investigation. Although two large and five small pig farms were available, only two farms' owners were willing to participate, so these two farms were selected for inclusion. A sample size of 384 pigs was recruited for the study following the formula described by Thrusfield (2005). Study subjects were randomly selected regardless of their health status, age, sex and body condition. For each recruited study subject, a general physical examination was conducted and data on age, sex and body condition score were recorded on a structured data sheet. Data on age of individual study subjects was retrieved from farm record books whilst animals were categorised as piglets ( $<10$ weeks), growers (10-16 weeks) or adult pigs ( $>16$ weeks), according to Keshaw et al. (2009). The body condition score was determined based on assessment of fat cover on their spine and transverse spinal process (Holness 1991). Generally, as found by Teshale (2005), the husbandry practice of the farms was not of a high standard; they were poorly managed with limited husbandry and health care practices. In addition, both farms had similar management practices and owned 1338 pigs (Farm 1) and 652 pigs (Farm 2) at the time of study.

\section{Sample collection and analysis}

Fresh faecal samples were collected directly from the rectum of the 384 pigs (289 from Farm 1 and 95 from Farm 2). The samples were placed in separate plastic containers and transported in an ice box to the parasitology laboratory of the College of Agricultural and Veterinary Medicine, Addis Ababa University for immediate processing or stored in the refrigerator at $4{ }^{\circ} \mathrm{C}$ for a day before processing. The faeces were examined by the centrifugal faecal floatation technique for eggs of nematodes, cestodes and coccidian oocysts, and the sedimentation technique for the presence of trematode eggs (Soulsby 1982; Urquhart et al. 1996). During physical examination from pigs that had clinical skin lesions, skin scrapings were collected by scraping the edges of the lesions using scalpel blades until capillary bleeding was seen and were preserved in labelled bottles containing $10 \%$ formalin and transported to the laboratory. Thereafter, they were placed for $30 \mathrm{~min}$ in Petri dishes containing 10\% potassium hydroxide. The samples were examined for the presence of mites and identification was carried out according to the standard techniques recommended by Soulsby (1982) and Urquhart et al. (1996).

\section{Data analysis}

The data were entered into a Microsoft Excel spreadsheet and coded appropriately. For data analysis, SPSS version 16 was used. Descriptive statistics were used to determine the prevalence of parasites in pigs. The chi-square test was used to determine the association between the infection and the risk factors such as age, body condition score and sex. In all cases, 95\% confidence intervals and $p<0.05$ were set for significance.

\section{Results}

Of the total 384 pigs examined, 25\% (96/384) were found to harbour one or more parasite species. Mixed infection was 
observed in $3.65 \%(n=14)$ of the pigs. In this study, four GIT parasites and one species of ectoparasite were identified. The GIT parasites identified were Coccidia (12\%), A. suum $(4.9 \%)$, strongyles $(5.2 \%)$ and Trichuris suis $(2.9 \%)$. The prevalence of mange mite infestation was $2.6 \%(n=10)$ and only S. scabiei var suis was identified from all 10 skin scraping samples collected from the suspected lesions. The frequency of occurrence and prevalence of parasites identified in this study is summarised in Table 1.

The occurrence of parasitic infestation was higher in grower pigs $(29.7 \%)$ than in piglets $(19.9 \%)$ and adult pigs $(23.1 \%)$. There was no significant difference $(p>0.05)$ in infection rate of GIT parasites amongst the different risk factors. However, the occurrence of parasites was significantly higher in Farm 1 than in Farm $2(p<0.05)$, with a prevalence of $31.1 \%$ in Farm 1 and $15.1 \%$ in Farm 2. In addition, the occurrence of S. scabiei var. suis was also significantly higher $(p<0.05)$ in piglets than in growers and adults. The distribution of parasites according to sex, age and body condition score of swine is listed in Table 2.

\section{Discussion}

Of the 384 pigs examined, $23.96 \%(n=92)$ were found to harbour one or more parasite species. However, this is lower than the findings of Abdu and Gashaw (2010) in Holeta, Ethiopia, Keshaw et al. (2009) in the West Indies, and Nganga et al. (2008) and Kagira et al. (2008) in Kenya, who recorded prevalences of $30.4 \%, 68.78 \%, 67.8 \%$ and $84.2 \%$, respectively. These variations in the prevalence of pig parasitic infections

TABLE 1: Prevalence of parasites identified by faecal and skin scraping examination in 384 pigs in Bishoftu.

\begin{tabular}{llll}
\hline Parasites & Parasite species & $\begin{array}{l}\text { Number of } \\
\text { infected pigs }\end{array}$ & Prevalence (\%) \\
\hline $\begin{array}{l}\text { Gastrointestinal } \\
\text { parasites }\end{array}$ & Coccidia & 46 & 12.0 \\
& Ascaris suum & 19 & 4.9 \\
& Strongyles & 20 & 5.2 \\
& Trichuris suis & 11 & 2.9 \\
& Total & 96 & $\mathbf{2 5 . 0}$ \\
External parasites & $\begin{array}{l}\text { Sarcoptes scabiei } \\
\text { var. suis }\end{array}$ & 10 & 2.6 \\
\hline
\end{tabular}

could be a result of the difference in management systems, breed of pig, nutrition, climatic factors and animal health extension services in countries. The statistically significant difference ( $p=0.007$ ) in the prevalence of parasites between the two farms (31.1\% for Farm 1 and $15.1 \%$ for Farm 2 ) could be ascribed to the difference in the number of samples taken from each farm.

The overall prevalence of Coccidia in this study was $12 \%$, which is higher than that reported by Abdu and Gashaw (2010), who recorded 5.6\% prevalence in and around Holeta, Ethiopia from semi-intensive and extensive farming systems. Studies conducted by Keshaw et al. (2009) in the West Indies, Weka and Ikeh (2009) in Jos metropolis, Nigeria and Weng et al. (2005) in China also indicated prevalences of $88 \%, 15.6 \%$ and $47.2 \%$, respectively. This variation could be because of the difference in pig husbandry practices in the various study areas. Several species of Eimeria and Isospora suis have been identified from pigs (Cañon-Franco, Henão-Agudelo \& Pérez-Bedoya 2012; Eysker et al. 1994; Mundt et al. 2005). In piglets, coccidiosis causes poor performance during the fattening period as well as diarrhoea, and also predisposes the animal to secondary bacterial and viral infections (Koudela \& Vítovec 1998; Lindsay, Blagburn \& Powe 1992; Stuart et al. 1982).

The prevalence of strongyle ova in this study was $5.2 \%$. This figure is lower than those reported by Kagira et al. (2008) in Kenya, Marufu et al. (2008) in Zimbabwe and Keshaw et al. (2009) in the West Indies, who reported a prevalence of 37\%, $14 \%$ and $44 \%$, respectively. The most common strongyles identified were Oesophagostomum spp., Hyostrongylus rubidus and Trichostrongylus axei (Keshaw et al. 2009; Marufu et al. 2008; Nganga et al. 2008). These parasites are responsible for loss of appetite, poor growth rate and poor feed conversion efficiency, and also predisposes animals to other pathogens and death in pigs (Stewart \& Hoyt 2006).

Ascaris suum was recovered at a prevalence of $4.9 \%$. This is lower than those reported by Abdu and Gashaw (2010) in Holeta and Zewdneh et al. (2013) in Tigrai, Ethiopia, Nganga et al. (2008) and Kagira et al. (2008) in Kenya and

TABLE 2: Distribution of parasites according to farm, sex, age and body condition score of pigs in Bishoftu.

\begin{tabular}{|c|c|c|c|c|c|c|c|c|c|c|c|c|c|c|}
\hline \multirow[t]{2}{*}{ Risk factor } & \multirow[t]{2}{*}{$\begin{array}{l}\text { Category } \\
\text { level }\end{array}$} & \multirow[t]{2}{*}{$N$} & \multicolumn{2}{|c|}{$\begin{array}{c}\text { Parasitic } \\
\text { infestation }\end{array}$} & \multicolumn{2}{|c|}{ Coccidia } & \multicolumn{2}{|c|}{ Ascaris suum } & \multicolumn{2}{|c|}{ Strongyle } & \multicolumn{2}{|c|}{ Trichuris suis } & \multicolumn{2}{|c|}{$\begin{array}{c}\text { Sarcoptes scabiei } \\
\text { var. suis }\end{array}$} \\
\hline & & & $n$ & $\%$ & $n$ & $\%$ & $n$ & $\%$ & $n$ & $\%$ & $n$ & $\%$ & $n$ & $\%$ \\
\hline \multirow[t]{2}{*}{ Farm } & Farm 1 & 289 & 90 & 31.1 & 37 & 12.8 & 13 & 68.4 & 17 & 5.9 & 9 & 3.1 & 8 & 2.8 \\
\hline & $P$-value & - & 0.007 & - & 0.386 & - & 0.479 & - & 0.3 & - & 0.609 & - & 0.725 & - \\
\hline \multirow[t]{2}{*}{ Sex } & Male & 153 & 35 & 22.9 & 14 & 9.2 & 10 & 6.5 & 4 & 2.6 & 6 & 3.9 & 1 & 0.7 \\
\hline & Female & 231 & 57 & 24.7 & 32 & 13.9 & 9 & 3.9 & 16 & 6.9 & 5 & 2.2 & 9 & 3.9 \\
\hline \multirow[t]{4}{*}{ Age } & Piglet & 136 & 27 & 19.9 & 13 & 9.6 & 5 & 3.7 & 6 & 4.4 & 5 & 3.7 & 2 & 1.5 \\
\hline & Grower & 118 & 35 & 29.7 & 20 & 16.9 & 6 & 5.1 & 9 & 7.6 & 2 & 1.7 & 1 & 0.8 \\
\hline & Adult & 130 & 30 & 23.1 & 13 & 10.0 & 8 & 6.2 & 5 & 3.8 & 4 & 3.1 & 7 & 5.4 \\
\hline & $P$-value & - & 0.181 & - & 0.135 & - & 0.646 & - & 0.357 & - & 0.630 & - & 0.048 & - \\
\hline \multirow{3}{*}{$\begin{array}{l}\text { Body condition } \\
\text { score }\end{array}$} & Good & 311 & 73 & 23.5 & 37 & 11.9 & 15 & 4.8 & 13 & 4.2 & 11 & 3.5 & 7 & 2.3 \\
\hline & Medium & 73 & 19 & 26.0 & 9 & 12.3 & 4 & 5.5 & 7 & 9.6 & 0 & 0.0 & 3 & 4.1 \\
\hline & $P$-value & - & 0.645 & - & 0.919 & - & 0.816 & - & 0.061 & - & 0.103 & - & 0.369 & - \\
\hline
\end{tabular}


Permin et al. (1999) in Ghana. Larval migration of A. suum is one of the causes of milk spot hepatic lesions in growing pigs. It also depresses weight gain by up to $40 \%$ and feed conversion efficiencies by up to $25 \%$ (Polley \& Mostert 1980). The thick-shelled eggs of A. suum are resistant to adverse environmental factors as well as chemicals and can maintain infectivity for long periods of time (Roepstorff \& Nansen 1998).

The prevalence of $T$. suis in this study was $2.9 \%$. Studies conducted by Zewdneh et al. (2013) in Tigrai (Ethiopia), Kagira et al. (2008) in Kenya, Marufu et al. (2008) in Zimbabwe, Permin et al. (1999) in Ghana, Weng et al. (2005) in China, Keshaw et al. (2009) in the West Indies and Nissen et al. (2011) in Uganda reported a prevalence of $0.3 \%, 7 \%, 4.7 \%, 4.6 \%$, $5.2 \%, 38 \%$ and $17 \%$, respectively. Sporadic disease caused by heavy infestation by T. suis is more common in pigs and is associated with watery diarrhoea that usually contains blood. The most important feature of Trichuris spp. is the longevity of the eggs in the environment, which can be up to 3 or 4 years (Urquhart et al. 1996).

The overall prevalence of $S$. scabiei var. suis in this study was $2.6 \%$, which was lower than that reported by Abdu and Gashaw (2010) in extensive and semi-intensive swine farms in and around Holeta, Ethiopia, where a prevalence of $16.2 \%$ was reported. There was a significant difference $(p=0.048)$ in the prevalence of $S$. scabiei var. suis amongst the age groups, with a prevalence of $5.4 \%, 0.8 \%$ and $1.5 \%$ in adults, growers and piglets, respectively. Both sarcoptic and demodectic mange mites have been reported as the causal agent for swine mange mite infestation (Soulsby 1982; Urquhart et al. 1996). However, sarcoptic mange caused by S. scabiei var. suis is the most common and serious ectoparasitic problem in swine (Das et al. 2010; Galuppi et al. 2007).

\section{Conclusion}

This study clearly shows that parasitic infections are prevalent in pigs in the study area. However, the attention given to pig diseases in general and parasitic diseases in particular so far has not been sufficient. In the absence of detailed studies on parasitic diseases of pigs in Ethiopia, their negative impact on pig production will continue unabated. Therefore, comprehensive studies are necessary to obtain a clear epidemiological picture of pig parasitic diseases, their burden and their impact on production. In addition, appropriate control measures such as strategic application of acaricides, deworming with appropriate drugs and good sanitation should be undertaken to reduce the impact of parasitic diseases on pig health and production.

\section{Acknowledgements}

The authors thank the owners of swine farms for their cooperation during sample collection and the staff of the Parasitology Laboratory of the College of Agricultural and Veterinary Medicine, Addis Ababa University for their support during sample processing.

\section{Competing interests}

The authors declare that they have no financial or personal relationships which may have inappropriately influenced them in writing this article.

\section{Authors' contributions}

A.J. (Alage Agricultural Technical Vocational Education Training College) designed the study, conducted laboratory work and prepared the manuscript. N.A. (Mekelle University), F.T. (Addis Ababa University), Y.T. (Mekelle University) and B.H. (Mekelle University) participated in the design of the study, analysis and interpretation of the data and preparation of the manuscript.

\section{References}

Abdu, S. \& Gashaw, A., 2010, 'Production system dynamism and parasitic interaction of swine in and around Holetta, Ethiopia', Ethiopian Veterinary Journal 14, 71-81.

Bakut, D.F., Shinggu, P.A. \& Nwosu, C.O., 1997, 'Gastrointestinal parasites of pigs in the semi-arid region of North-Eastern Nigeria', Bulletin of Animal Health and Production in Africa 45, 111-113.

Caballero-Hernández, A.I., Castrejón-Pineda, F., Martinez-Gamba, R., AngelesCampos, S., Pérez-Rojas, M. \& Buntinx, S.E., 2004, 'Survival and viability of Ascaris suum and Oesophaphagostomum dentatum in ensiled swine faeces', Bioresource Technology 94, 137-142. http://dx.doi.org/10.1016/j.biortech.2003.12.008

Cañon-Franco, W.A., Henão-Agudelo, R.A. \& Pérez-Bedoya, J.L., 2012, 'Recovery of gastrointestinal swine parasites in anaerobic biodigester systems', Revisto Brasileira de Parasitologia Veterinária 21(3), 249-253. http://dx.doi.org/10.1590/ S1984-29612012000300013

Damriyasa, I.M., Failing, K., Volmer, R., Zahner, H. \& Bauer, C., 2004, 'Prevalence, risk factors and economic importance of infestations with Sarcoptes scabiei and Haematopinus suis in sows of pig breeding farms in Hesse, Germany', Medical and Veterinary Entomology 18, 361-367. http://dx.doi.org/10.1111/j.0269283X.2004.00520.x

Das, M., Laha, R., Devi, P., Bordoloi, R.K. \& Naskar, S., 2010, 'Sarcoptic mange infestation in pigs in a hilly region of Meghalaya', Tropical Animal Health and Production 42, 1009-1011. http://dx.doi.org/10.1007/s11250-009-9523-4

Davis, D.P. \& Moon, D., 1990, 'Density location and sampling of sarcoptes scabies on experimentally infected pigs', Journal of Medical Entomology 27, 391-398. http://dx.doi.org/10.1093/jmedent/27.3.391

Dewey, C.E., Wohlgemut, J.M., Levy, M. \& Mutua, F.K., 2011, 'The impact of political crisis on smallholder pig farmers in western Kenya, 2006-2008', Journal of Modern African Studies 49(3), 455-473. http://dx.doi.org/10.1017/S0022278X11000280

Eysker, M., Boerdam, G.A., Hollanders, W. \& Verheijden, J.H., 1994, 'The prevalence of Isospora suis and Strongyloides ransomi in suckling piglets in The Netherlands', Veterinary Quarterly 16, 203-205. http://dx.doi.org/10.1080/0165 2176.1994.9694449

Food and Agriculture Organization of the United Nations (FAO), 2012, FAO Animal Production and Health Livestock Countries Review: Pig sector Kenya, Rome, Italy, viewed October 25 2014, from http://www.fao.org/docrep/015/i2566e/ i2566e00.pdf

Food and Agriculture Organization Statistics Division (FAOSTAT), 2005, FAOSTAT Online Database, viewed October 25 2014, from http://faostat.fao.org/faostat/ collections?subset=agriculture

Galuppi, R., Avenoso, A.M., Leotti, G., Ostanello, F., Poglayen, G. \& Tampieri, M.P., 2007 , 'Diagnosis of sarcoptic mange in slaughtered swine', Veterinary Research Communications 31, 233-236. http://dx.doi.org/10.1007/s11259-007-0013-8

Hailu, M., Tarekegn, A., Tessema, A. \& Damte, K., 2014, 'Panel discussion on assessing the challenges and opportunities of small-scale pig production in Amhara Region', College of Agriculture and Environmental Sciences, Bahir Dar University, Ethiopia, viewed February 26 2014, from http://www.w3.org/WAl/ bcase/benefits.htm

Hale, O.M. \& Stewart, T.B., 1987, 'Feed and maintenance costs of internal parasites in growing-finishing swine', Agri-Practice 8(4), 33-35.

Hale, O.M. \& Stewart, T.B., 1998, 'Losses to internal parasites in swine production', Journal of Animal Sciences 66, 1548-1554.

Hale, O.M., Stewart, T.B. \& Marti, O.G., 1986, 'Endoparasite effects on performance of pigs', Pig News and Information 7(4), 439-441.

Holness, D.H., 1991, The tropical agriculturalist (Pigs), CTA, Wageningen.

Kagira, J.M., Kanyari, P.W.N., Waruiru, R.M. \& Munyua, W.K., 2008, 'Relationship between the prevalence of gastrointestinal nematode infections and management practices in pig herds in Thika District, Kenya', Livestock Research for Rura Development 20(10), 106-113.

Keshaw, P.T., Alfred, C., Guillaume, B., Guillaume, V., Claude, D., Graeme, S. et al., 2009, 'Prevalence of intestinal parasites in pigs in Grenada, West Indies', West Indian Veterinary Journal 9, 22-27. 
Koudela, B. \& Vítovec, J., 1998, 'Biology and pathogenicity of Eimeria neodebliecki Vetterling, 1965 in experimentally infected pigs', Parasitology International 47(4) 249-256. http://dx.doi.org/10.1016/S1383-5769(98)00030-0

Kumsa, B. \& Kifle, E., 2014, 'Internal parasites and health management of pigs in Burayu District, Oromia Regional State, Ethiopia', Journal of the South African Veterinary Association 85(1), Art. \#913, 5 pages. http://dx.doi.org/10.4102/jsava. v85i1.913

Lekule, F.P. \& Kyvsgaard, N.C., 2003, 'Improving pig husbandry in tropical resource-poor communities and its potential to reduce risk of porcine cysticercosis', Acta Tropica 87, 111-117. http://dx.doi.org/10.1016/S0001706X(03)00026-3

Lindsay, D.S., Blagburn, B.L. \& Powe, T.A., 1992, 'Enteric coccidial infections and coccidiosis in swine', Compendium on Continuing Education for the Practising Veterinarian 14, 698-702.

Marufu, M.C., Chanayiwa, P., Chimonyo, M. \& Bhebhe, E., 2008, 'Prevalence of gastrointestinal nematodes in Mukota pigs in a communal area of Zimbabwe' African Journal of Agricultural Research 3, 91-95.

Mundt, H.C., Cohnen, A., Daugschies, A., Joachim, A., Prosl, H., Schmäschke, R. et al., 2005, 'Occurrence of Isospora suis in Germany, Switzerland and Austria', Journal of Veterinary Medicine 52, 93-97. http://dx.doi.org/10.1111/j.14390450.2005.00824.x

National Metrological Surveillance Agency (NMSA), 2003, 'Monthly report on temperature and rainfall distribution', Ethiopia Metrological Office, Addis Ababa Ethiopia.

Nganga, C.J., Karanja, D.N. \& Mutune, M.N., 2008, 'The prevalence of gastrointestinal helminthes infections in pigs in Kenya', Tropical Animal Health and Production 40 331-334. http://dx.doi.org/10.1007/s11250-007-9112-3

Nissen, S., Poulsen, I.H., Nejsum, P., Olsen, A., Roepstorff, A., Rubaire-Akiiki, C. et al., 2011, 'Prevalence of gastrointestinal nematodes in growing pigs in Kabale Distric in Uganda', Tropical Animal Health and Production 43, 567-572. http://dx.doi. org/10.1007/s11250-010-9732-x

Nosal, P. \& Eckert, R., 2005, 'Gastrointestinal parasites of swine in relation to the age group and management system', Medycyna Weterynaryjna 61, 435-438.

Oluwafemi, R.A., 2008, 'Gastro-intestinal helminths and public health: Overview of a neglected sector', International Journal of Veterinary Medicine 4(2), 72-78.

Onah, D.N. \& Chiejina, S.N., 1995, 'Taenia solium cysticercosis and human taeniasis in the Nsukka area of Enugu State, Nigeria', Annals of Tropical Medicine and Parasitology 89, 399-407.

Permin, A., Yelifari, L., Bloch, P., Steenhard, N., Hansen, N.P. \& Nansen, P., 1999 'Parasites in cross-bred pigs in upper East region of Ghana', Veterinary Parasitology 87, 63-71. http://dx.doi.org/10.1016/S0304-4017(99)00159-4
Phiri, I.K., Ngowi, H., Afonso, S., Matenga, E., Boa, M., Mukaratirwa, S. et al., 2003, 'The emergence of Taenia solium cysticercosis in eastern and southern Africa as a serious agricultural problem and public health risk', Acta Tropica 87, 13-23. http://dx.doi.org/10.1016/S0001-706X(03)00051-2

Polley, L.R. \& Mostert, P.E., 1980, 'Ascaris suum in Saskatchewan pigs: An abattoir survey of prevalence and intensity of infection', Canadian Veterinary Journal 21(11), 307-309.

Roepstorff, A. \& Nansen, P., 1998, Epidemiology, diagnosis and control of helminth parasites of swine, FAO Animal Health Manual No. 3, Food \& Agriculture Organization of the United Nations, Rome.

Sangeeta, K., Prasad, K.D. \& Singh, S., 2002, 'Study on some factors influencing the incidence of GIT parasitism in pigs', Indian Journal of Animal Health 44, 77-80.

Serres, H., 2001, Manual of pig production in the Tropics, 3rd edn., Biddies Press, Wallingford.

Soulsby, E.J.L., 1982, Helminths, arthropods and protozoa of domestic animals, 7th edn., Clows, London.

Stewart, B.T. \& Hoyt, P.G., 2006, 'Internal parasites', in B.E. Straw, J.J. Zimmerman, S D’Allaire \& D.J. Taylor (eds.), Diseases of swine, 9th edn., pp. 901-914, Ames, lowa.

Stewart, T.B. \& Hale, O.M., 1988, 'Losses to internal parasites in swine production', Journal of Animal Science 66, 1548-1554.

Stuart, B.P., Gosser, H.S., Allen, C.B. \& Bedell, D.M., 1982, 'Coccidiosis in swine: Dose and age response to Isospora suis', Canadian Journal of Comparative Medicine 46, 317-320.

Teshale, S., 2005, 'Recent footrot outbreak in Debrezeit swine farm, central Ethiopia', Journal of Veterinary Science 6(4), 367-368.

Thrusfield, M., 2005, Veterinary epidemiology, 3rd edn., Blackwell Science, Oxford.

Urquhart, G.M., Armour, J., Duncan, J.I., Dunn, A.M. \& Jennings, F.W., 1996, Veterinary parasitology, 2nd edn., Blackwell Science, London.

Weka, R.P. \& Ikeh, E.I., 2009, 'Seroprevalence of cysticercosis and intestinal parasitism in pigs in Jos metropolis', Journal of Animal and Veterinary Advances 8, 883-887. http://dx.doi.org/10.3923/javaa.2009.883.887

Weng, Y.B., Hu, Y.J., Li, Y., Li, B.S., Li, R.Q., Xie, D.H. et al., 2005, 'Survey of intestinal parasites in pigs from intensive farms in Guangdong province, People's Republic of China', Veterinary Parasitology 127, 333-336. http://dx.doi.org/10.1016/j. vetpar.2004.09.030

Zewdneh, T., Ekwal, I., Tsegabirhan, K., Yohannes, T. \& Kidane, W., 2013, 'Prevalence of gastrointestinal parasites and Cryptosporidium spp. in extensively managed pigs in Mekelle and urban areas of southern zone of Tigray region, Northern Ethiopia', Veterinary World 6(7), 433-439. http://dx.doi.org/10.5455/ vetworld.2013.433-439 